\title{
Self-Assessment on Integrated Listening-Writing Skills for Human Puppets Preservation
}

\author{
Hermayawati \\ Faculty of Teachers Training and Education, Universitas Mercu Buana Yogyakarta, Indonesia \\ Received December 30, 2019; Revised February 12, 2020; Accepted February 24, 2020
}

Copyright $\mathrm{C} 2020$ by authors, all rights reserved. Authors agree that this article remains permanently open access under the terms of the Creative Commons Attribution License 4.0 International License

\begin{abstract}
This study examines the application of self-assessment concerning students writing skills using integrated CLLA (Cultural Language Learning Approach), BLM (Blended Learning Method) and HOTS (High Order Thinking Skills) with human puppets serial stories what so-called Wayang Orang (WO) as the learning discourses. This was intended to implement Self-Assessment to the students' listening-writing skills development using integrated CLLA, BLM and HOTS as WO preservation efforts for the sake of finding the concept of implementing Self-Assessment on Listening-Writing Skills (SALWS) using such three methods. The Mixed Methods Study was conducted by involving 30 students of the English Education Program Faculty of Teachers Training and Education. The main data was a portfolio of documentation of SALWS assignments analyzed using the Eberly Center for Teaching Excellence Carnegie Mellon Model (ECTECM). The results were interpreted as findings regarding the SALWS implementation integrated with CLLA, BLM and HOTS containing with various WO serial stories. The study reveals that SALWS can be used as a self-assessment guide by students for the average score spreads between $0 \%$ for $\mathrm{A}$ (sophisticated) scores, $6 \% \mathrm{~B}$ scores (very competent), 71\% C scores (competent), and the remaining $11 \%$ get scores $\mathrm{D}$ (Not yet competent). WO preservation efforts conducted in the Paragraph-Writing class could attract a majority of $89 \%$ of students. The rest neither were interested in WO nor increased such language skills since they came from foreign countries which were still in the process of adaptation in using both their English and Indonesian.
\end{abstract}

Keywords Self-Assessment, CLLA, HOTS, Blended Learning, SALWS

\section{Introduction}

The existence of cultural products, especially the
Wayang Orang (Human Puppets) show in Indonesia, is now slowly becoming obsolete, especially by the younger generation as evidenced by the lack of visitors in all theater buildings (Gemilang, 2010) whereas every serial of WO story contains noble moral values, in addition to displaying artistic and adorable work of art. This fact of course must get seriously attention from all parties, including the writer as a faculty member of a university. WO must be at least introduced among the higher level students, particularly of Teachers Training and Education Faculty through the implementation of CLLA (Cultural Language Learning Approach). Such approach can be utilized as learning media with the serial stories adopted from the You Tube. As it is known, several Wayang (Puppets) serial stories both the Mahabharata and Ramayana are currently available in the You Tube. The serials are uploaded by the traditional sympathizers who seriously wish to participate in preserving one of the valuable ancestral cultures. To support such preservation efforts, the WO performances provided in the You Tube can be used as the learning materials, especially for the language department through Blended Learning Model (BLM).

As an effort, these interests has actually been supported by the development of science and technology (Science, Technology and Art) which is currently accessible through gadgets. The existence of the device as one of the products of technological development is identical to the existence of learners in the current era of Industrial Revolution 4.0. Through the device, relatively all the needs of learning materials can be accessed for example through You Tube, Messenger, Facebook Blog, Instagram and VLOG (Video Blog) using BLM.

Blended Learning Model (BLM) is one of the learning models by combining the existence of digital technology with the learning process both in the classroom and outside the classroom (Thomson, 2016; TeachThought Staff, 2018). Utilization of the model is in accordance with the concept of HOTS (High Order Thinking Skills) as a result of the development of Bloom's Taxonomy by 
Anderson and Krathwohl (2002), which has recently been developed in the world of education including English language education (ELE) in the tertiary education institutions.

This study examined the implementation of self-assessment techniques for learning 'Writing' courses in the English Study Program, Faculty of Teachers Training and Education by using CLLA, BLM and HOTS at once. The results of the study can then be used as the basic of implementing self-assessment on the students' own writing tasks. This study was conducted by considering the needs analysis (NA) of the following parties: students, tertiary education institutions, both regional and central government, users community of the graduates for the sake of facing forthcoming global challenges but keep concerning to local wisdom.

This project utilized what so-called Wayang Orang (Human Puppets) performances especially of the "Sekar Budaya Nusantara (SBN)" group presented on the You Tube site. SBN is a WO group which was formerly one of the national television programs of the Republic of Indonesia Television (TVRI) in the era of the New Order Regime government and was initiated by a former Minister of Social and Culture Nani Soedarsono. SBN was established by Nani Soedarsono on September 11, 2002. The initiative to establish SBN was also based on the worsening and exclusion of indigenous cultures of Indonesia due to the rise of modern culture as an implication of foreign cultures.

The existence of cultural values in Indonesian society has shifted, its impact has also influenced the behavior and character of the community. The Indonesian nation which is formerly known as a civilized, polite and friendly nation tends to be a violent nation that is easily ignited by internal conflicts. Such conditions are far from the noble values and philosophies contained in the nation's traditional culture.

On the basis of such concerns, SBN seeks to rediscovery the grandeur of the values that exist behind the traditional arts that become the local wisdom of the Indonesian nation, then preserve the values of the majesty in order to become the identity of the Indonesian people (Anonymous, 2019). Various SBN performances were uploaded to YouTube by observers of Cultural Arts. This SBN group was taken as digital media because of its clearer shows with the best actors taken from various Wayang Orang (WO) associations, namely WO Bharata, Jakarta, WO RRI Surakarta, WO Sri Wedari Surakarta, and WO Ngesti Pandawa Semarang.

Various stories of the Ramayana and Mahabharata versions played by the SBN WO group were chosen as media as well as a source of learning discourse with the aim of participating in maintaining the increasingly woeful existence of the WO (Gemilang, 2010). In this case, the role of technology advancement can be employed as an appropriate alternative for introducing WO to the younger generation because of its ease of accessing wayang story serials performance compared to directly visiting the original stage where the WO shows its performance. The selected WO serial stories, which commonly spoke Javanese, were chosen as the integrated listening-writing materials. Listening activity which was carried out in Javanese story content, was, then, translated and paraphrased into written English tasks.
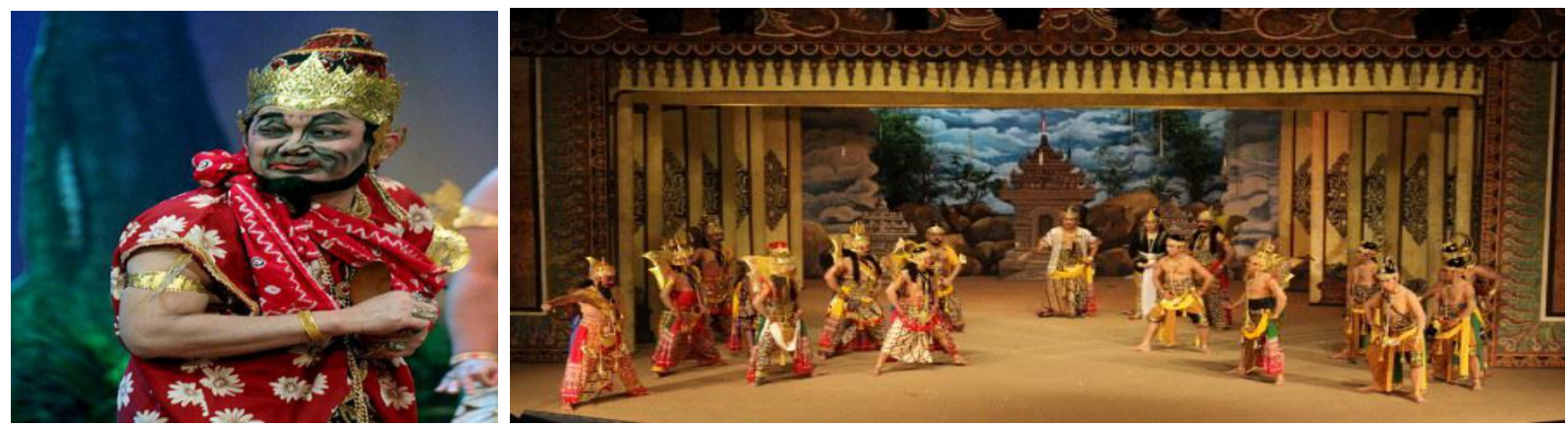

Source: http://sekarbudayanusantara.co.id/Wynk/?p=1768 downloaded February 8, 2019

Figure 1. Durna, the evil character of Astina and the Pandava knights together with Dewi Drupadi and Dewi Kunthi. Faced with the Korawa siblings, they are quoted from the Mahabharata story 

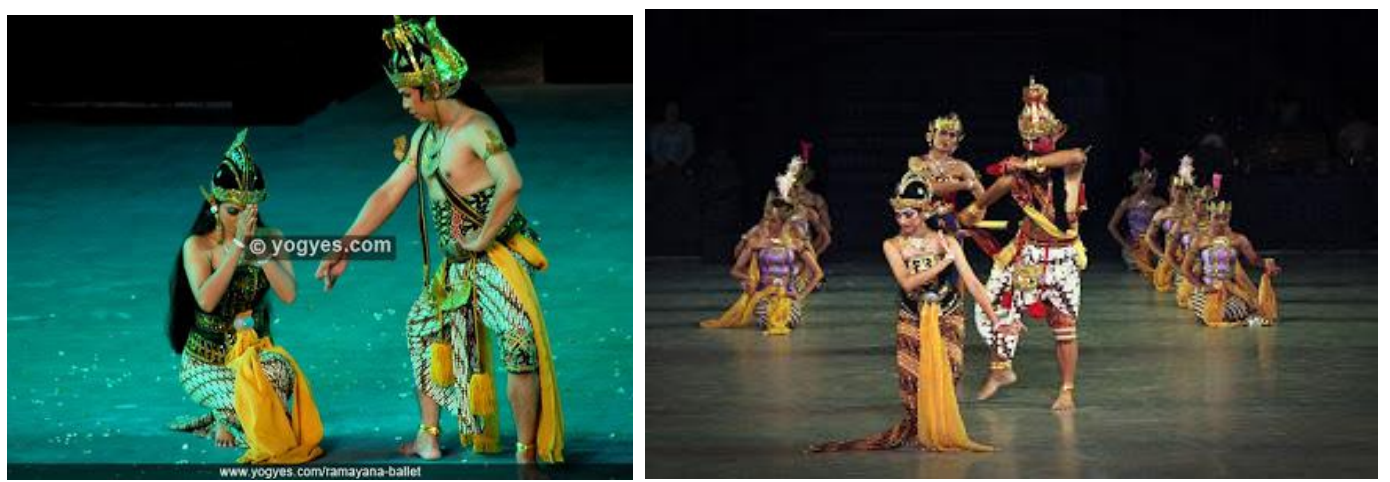

Source: http://supraba15.blogspot.com/2013/04/sejarah-asal-usul-wayang.html

Figure 2. Ramayana Episodes: King Rama Wijaya, Dewi Shinta, King Rahwana Raja and Shinta.

Integrated Language Skills (ILS) is defined as a nonfragmented language skills, including English Language skills (Kent \& Sarah, 2015). They interpret Integrated English Skills (IES) as Integrated Skills of English (ISE) as exams that assess all four language skills, namely: reading, writing, speaking and listening in a way that reflects real-life communication in English. Based on such understanding, the form of IES learning is conducted by combining the four skills of reading, writing, speaking and listening at the same time by directly reflecting it in actual communication.

Slightly different from the above concept, this study employed ILS as a technique to comprehend the Javanese and/or Indonesian wayang story discourse, which was, then, paraphrased into English in written form using the students' own English styles. The Writing tasks were done in groups where each group must have at least a Javanese to enable them to understand the contents of learned Javanese wayang stories accessed from the You Tube.

The learning procedure is as follows. Firstly, the class is divided into three groups. Secondly, the groups watch the certain selected wayang story accessed from the You Tube. Thirdly, they are asked to comprehend and rewrite the main points of the story in English with the format Introduction, Content and Conclusions in the form of synopsis. Fourth, the group work are, then, discussed in the class to match the understanding of each group. Finally, they were asked to rate the results of each group's writing work independently (self-assessment) using the suggested scoring rubrics.

In line with the ISE concept, Rebecca (2001) asserts that there are two types of integrated English learning approaches, namely content-based language instruction (CBI) and task-based instruction (TBI). CBI develops learning content through language, while TBI places more emphasis on working on tasks that require the use of language in a practical manner (communicative language use). Although there are differences regarding the learning techniques, there are similarities in both of them using literature such as news, textbooks, papers and the like. In addition, the use of both approaches to language learning is, that they require understanding subject matter content with a high level of complexity. This kind of understanding certainly requires a higher order level of thinking (HOTS).

Conceptually, learning language skills cannot be separated each other, particularly in the practical language use such as: reading skill (which in this case reading running texts that accompany the display of story images), listening (listening to the storyline or narrative mastermind and the perpetrator's conversation), writing (done while doing the task of writing synopsis texts narratively) and speaking (done when describing the contents of the puppet story) with the group and / or with other groups. The purpose of his presentation is to emphasize the truth of each group's understanding of the contents of the puppet serial stories they watch and the content of the characters or moral messages embedded in the stories.

Some of the story points accessed from both the Ramayana and Mahabharata series were listened to and discussed in groups. The selected Ramayana series were among others "Sugriwa Subali" and "Wahyu Makutharama" and the Mahabharata series to be accessed were episodes of "Karna Sumbaga" and Babad Alas Wanamarta. Table 1 presents stories that were deliberately chosen as either the written materials or as self-assessment materials.

This study refers to the third type of Blended Learning Involvement, namely: "Learning is done by combining instructional technology (Instructional Technology) and the actual assignment in order to create harmony between learning and work (theory and practice)". In this case, the learning process was carried out using WO material selected from YouTube, understood and written in the form of English-language synopsis using the students' own vocabulary and the results were self-assessed using scoring rubrics for predetermined writing skills, namely the Eberly Center for Teaching Excellence Model Carnegie Mellon (MECTECM). 
Table 1. Procedure on the WO Stories Learning Using CLLA

\begin{tabular}{|c|c|c|}
\hline Story Series & \multicolumn{2}{|l|}{ Integrated Language Skills Activities } \\
\hline Ramayana & Listening \& Reading & Writing \& Speaking \\
\hline $\begin{array}{ll}\text { - } & \text { Sugriwa Subali } \\
\text { - } & \text { Wahyu Makutarama }\end{array}$ & $\begin{array}{l}\text { - Watching video while reading its } \\
\text { running text; } \\
\text { Responding instructor's questions }\end{array}$ & $\begin{array}{l}\text { - Writing the main points content and its } \\
\text { moral messages; } \\
\text { - } \quad \text { Discussing the works representatively } \\
\text { - Self-Assessing group works }\end{array}$ \\
\hline Mahabharata & Listening \& Reading & Writing \& Speaking \\
\hline $\begin{array}{ll}\text { - } & \text { Karna Sumbaga } \\
\text { - } & \text { Babad Alas Wanamarta }\end{array}$ & $\begin{array}{l}\text { - Watching video while reading its } \\
\text { running text; } \\
\text { - } \quad \text { Responsing instructor's questions }\end{array}$ & $\begin{array}{l}\text { - Writing the main points content and its } \\
\text { moral messages; } \\
\text { - } \quad \text { Performing the works representatively }\end{array}$ \\
\hline
\end{tabular}

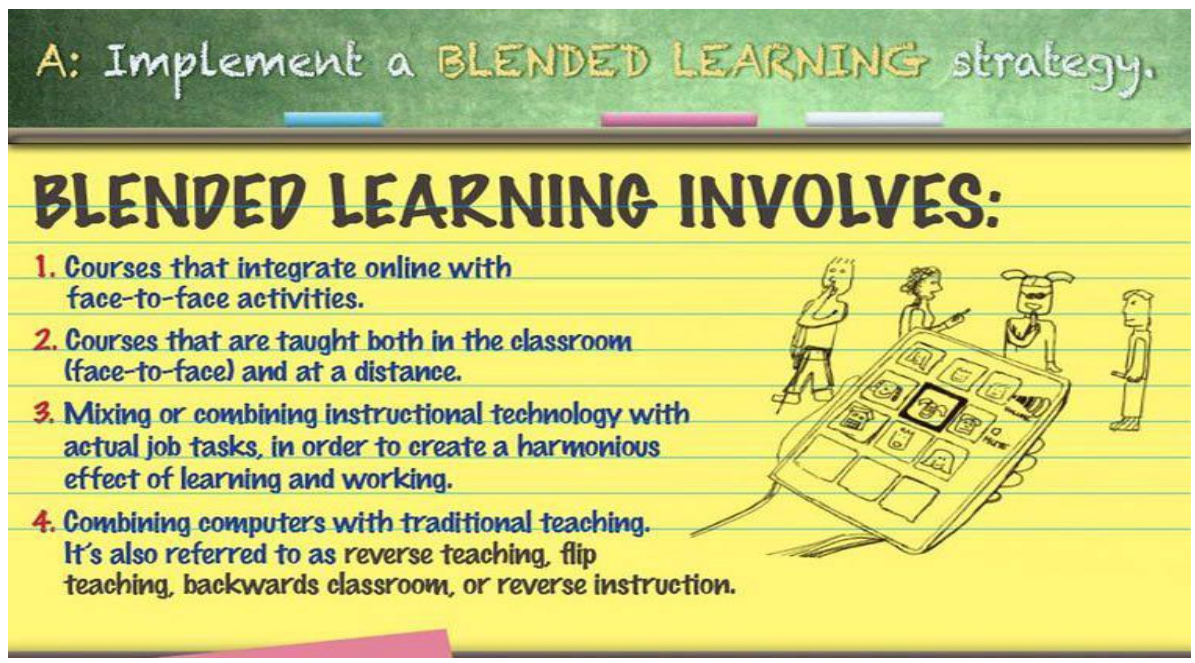

Source: https://www.teachthought. com/learning/12-types-of-blended-learning/

Figure 3. Activity Types of Blended Learning Model (TeachThought Staff, 2018)

\section{Blended Learning Model (BLM)}

BLM includes four types of activities, namely learning carried out in the following manner: (1) combining online and face-to-face activities; (2) inside or outside the classroom; (3) integrating instructional technology and actual assignment in order to create harmony between learning and work (theory and practice); and (4) integrating computer use and traditional learning (TeachThought Staff, 2018).

\section{Higher Order Thinking Skills (HOTS)}

Higher Order Thinking (HOTS) is an activity in the form of thinking techniques involving high-level cognitive hierarchical levels (Dafik, 2014; King et al., 2017; Merta et al., 2017). This theory is actually the result of the development of Bloom's taxonomy which was introduced in 1956 by Beniamin S. Bloom and is still currently adhered in the world of education. This cognitive taxonomy involves mastering six domains of thinking from the easiest to the highest, namely knowledge (recall or locate information), comprehension (understand learned facts), application (Apply what has been learned to new situations), analysis ('Take apart information to examine different parts), synthesis (create or invent something; bring together more than one idea) and evaluation (Consider evidence to support conclusion).

In its development, the six levels of cognitive thinking which are often referred to as $\mathrm{C} 1, \mathrm{C} 2, \mathrm{C} 3, \mathrm{C} 4, \mathrm{C} 5$ and $\mathrm{C} 6$ by Anderson and Krathwohl (2001) were developed at once simplified into remembering, understanding, applying, analyzing, evaluating and creating. The six domains of cognitive thinking so far have been widely applied by many experts and practitioners because it is easier to understand (Dafik, 2014). In a nutshell, the use of BLM can be conducted by making use of sources accessed from the internet to bring into the classroom learning activities by involving all of the learners' six cognitive levels of thinking comprehensively.

In line with the aforementioned BLM concept, this project employed such method by utilizing the selected serial of wayang stories of both Mahabharata and Ramayana accessed from You Tube in which contents were presented as the group discussion materials. The selected wayang stories were intentionally addressed to introduce either the actors and actresses' various characters (the good and the wicked) or the hidden moral value messages available in each stories. BLM fulfills the requirements to develop learners' higher thinking skills. 


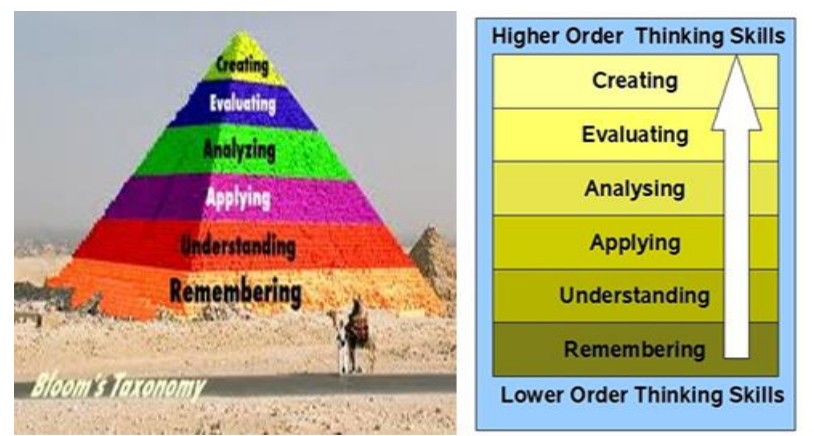

Figure 4. Domain of Taksonomi Bloom(Anderson \& Krathwohl, 2001)

In this study, HOTS was used as a basis for developing the realm of thinking of students of the PBI Writing Study Program FKIP, Mercu Buana University Yogyakarta (UMBY). In this case, the learning process was carried out in integrated inter-language skills (macro-skills), especially listening-writing and not separately from one skill to another (not in isolated way). Likewise learning aspects or components of the language (micro-skills) such as the mastery of new vocabulary, structure, grammar, spelling, diction and coherency were taught by imbedding the six domains into each discourse or topic being studied. Figure 4 presents the level of Bloom's taxonomic order which has been revised by Anderson \& Krathwohl (ibid: 2001).

\section{Self-Assessment on Integrated Listening-Writing Skills (SALWS)}

Self-Assessment on Integrated Listening-Writing Skills (SALWS) is one of the assessment techniques as an alternative to measure the success of learning independently (O'Malley \& Pierce, 2000). Performance levels of students in the Listening-Writing activities were assessed using Scoring Rubrics in sequence, namely: Excellent, Good, Fair, Poor categories with scores ranging from $0-5$. The highest scores are 5, Excellent, 4 Good, 2 and 3 Fair, 0-1 Poor.

Table 2 is one of the assessment guide models that are often used in assessing students' writing skills, which in this case are integrated with listening skills. However, listening activities in this study are limited to be used as a basis for writing students' understanding of the contents of various wayang stories presented in the form of videos. In other words, the emphasis on learning activities focuses more on writing story content in their own language. The results of his writing were then assessed independently using the Eberly Center for Teaching Excellence Carnegie Mellon scoring rubrics Model (ECTECM).

Table 2. Scoring Rubric for Writing Assessment inspired from Independent Writing Rubrics

\begin{tabular}{|c|c|}
\hline Score & Scoring Criteria \\
\hline 5 & $\begin{array}{l}\text { An essay at this level largely accomplishes all of the following: } \\
\text { Effectively addresses the topic and task; } \\
\text { Is well organized and well developed, using clearly appropriate explanations, exemplifications and/or details; } \\
\text { Displays unity, progression and coherence; } \\
\text { Displays consistent facility in the use of language, demonstrating syntactic variety, appropriate word choice and idiomaticity, } \\
\text { though it may have minor lexical or grammatical errors. }\end{array}$ \\
\hline 4 & $\begin{array}{l}\text { An essay at this level largely accomplishes all of the following: } \\
\text { Addresses the topic and task well, though some points may not be fully elaborated; } \\
\text { - Is generally well organized and well developed, using appropriate and sufficient explanations, exemplifications and/or details; } \\
\text { Displays unity, progression and coherence, though it may contain occasional redundancy, digression, or unclear connections; } \\
\text { - Displays facility in the use of language, demonstrating syntactic variety and range of vocabulary, though it will probably have } \\
\text { occasional noticeable minor errors in structure, word form or use of idiomatic language that do not interfere with meaning. }\end{array}$ \\
\hline 3 & $\begin{array}{l}\text { An essay at this level is marked by one or more of the following: } \\
\text { Addresses the topic and task using somewhat developed explanations, exemplifications and/or details; } \\
\text { Displays unity, progression and coherence, though connection of ideas may be occasionally obscured; } \\
\text { - May demonstrate inconsistent facility in sentence formation and word choice that may result in lack of clarity and } \\
\text { occasionally obscure meaning; } \\
\text { May display accurate but limited range of syntactic structures and vocabulary. }\end{array}$ \\
\hline 2 & $\begin{array}{l}\text { An essay at this level may reveal one or more of the following weaknesses: } \\
\text { - Limited development in response to the topic and task; } \\
\text { Inadequate organization or connection of ideas; } \\
\text { Inappropriate or insufficient exemplifications, explanations or details to support or illustrate generalizations in response to the } \\
\text { task; } \\
\text { - A noticeably inappropriate choice of words or word forms; } \\
\text { - An accumulation of errors in sentence structure and/or usage; }\end{array}$ \\
\hline 1 & $\begin{array}{l}\text { An essay at this level is seriously flawed by one or more of the following weaknesses: } \\
\text { - Serious disorganization or underdevelopment; } \\
\text { - Little or no detail, or irrelevant specifics, or questionable responsiveness to the task; } \\
\text { - Serious and frequent errors in sentence structure or usage; }\end{array}$ \\
\hline 0 & $\begin{array}{l}\text { An essay at this level merely copies words from the topic, rejects the topic, or is otherwise not connected to the topic, is written } \\
\text { in a foreign language, consists of keystroke characters, or is blank. }\end{array}$ \\
\hline
\end{tabular}

inspired by TOEFL IBT Scoring Rubric https://www.ets.org/s/toefl/pdf/toefl_writing_rubrics.pdf 
Table 3. Reflection Writing Rubric (Inspired by Eberly Center for Teaching Excellence Carnegie Mellon

\begin{tabular}{|c|c|c|c|c|}
\hline $\begin{array}{l}\text { Scoring } \\
\text { Criteria }\end{array}$ & Sophisticated (A) & Very Competent (B) & Competent (C) & Not Yet Competent (D) \\
\hline $\begin{array}{l}\text { Accuracy } \\
\text { (Grasp } \\
\text { readings) }\end{array}$ & $\begin{array}{l}\text { Paper represents the authors' } \\
\text { ideas, evidence or } \\
\text { conclusions accurately, fairly } \\
\text { and eloquently. Shows a firm } \\
\text { understanding of the } \\
\text { implications of each author's } \\
\text { argument(s). }\end{array}$ & $\begin{array}{l}\text { Paper represents the } \\
\text { author's ideas, evidence } \\
\text { and } \\
\text { accurately. }\end{array}$ & $\begin{array}{l}\text { Paper represents the } \\
\text { authors, ideas, evidence } \\
\text { and conclusions accurately } \\
\text { but not sufficiently clearly. } \\
\text { Minor inaccuracies. }\end{array}$ & $\begin{array}{l}\text { Paper misrepresents the } \\
\text { authors' ideas, evidence } \\
\text { and/or conclusions. } \\
\text { Major inaccuracies. Or } \\
\text { does not distinguish } \\
\text { between major ideas and } \\
\text { less relevant points. }\end{array}$ \\
\hline $\begin{array}{l}\text { Argument } \\
\text { (depth of } \\
\text { analysis) }\end{array}$ & $\begin{array}{l}\text { Paper fully meets } \\
\text { requirements of assignment. } \\
\text { Explores implications of } \\
\text { chosen ideas for the arts in } \\
\text { classical Greece or today in } \\
\text { thoughtful and/or original } \\
\text { ways. Makes convincing case } \\
\text { for why selected key ideas } \\
\text { connect (or contradict) two } \\
\text { texts, and/or connect } \\
\text { (contradict) texts and lectures. }\end{array}$ & $\begin{array}{l}\text { Paper fully meets the } \\
\text { requirements but does not } \\
\text { exceed them. Makes good } \\
\text { case for why selected key } \\
\text { ideas connect (or } \\
\text { contradict) two texts, } \\
\text { and/or connect } \\
\text { (contradict) texts and } \\
\text { lectures. }\end{array}$ & $\begin{array}{l}\text { Paper does not address } \\
\text { some aspects of the } \\
\text { assignment. Makes } \\
\text { somewhat unconvincing } \\
\text { case for why selected ideas } \\
\text { connect (contradict) two } \\
\text { texts, and/or connect } \\
\text { (contradict) texts and } \\
\text { lectures. }\end{array}$ & $\begin{array}{l}\text { Paper does not address } \\
\text { the assignment Selects } \\
\text { minor rather than key } \\
\text { ideas, and/or does not } \\
\text { show why the selected } \\
\text { ideas connect (or } \\
\text { contradict) texts, and/or } \\
\text { connect (contradict) texts } \\
\text { and lectures. }\end{array}$ \\
\hline Clarity & $\begin{array}{l}\text { Consistently precise and } \\
\text { unambiguous wording, clear } \\
\text { and lucid sentence structure. } \\
\text { All quotations are well } \\
\text { chosen, effectively framed in } \\
\text { the text and explicated where } \\
\text { necessary. }\end{array}$ & $\begin{array}{l}\text { Mostly precise and } \\
\text { unambiguous wording, } \\
\text { mostly clear sentence } \\
\text { structure. Mostly effective } \\
\text { choice of quotation. } \\
\text { Mostly effective framing } \\
\text { and explication of } \\
\text { quotation where } \\
\text { necessary. }\end{array}$ & $\begin{array}{l}\text { Imprecise or ambiguous } \\
\text { wording. Confusing } \\
\text { sentence structure. Poorly } \\
\text { chosen quotations, or } \\
\text { ineffective framing and } \\
\text { explication of quotations. }\end{array}$ & $\begin{array}{l}\text { Consistently imprecise or } \\
\text { ambiguous } \quad \text { wording, } \\
\text { confusing sentence } \\
\text { structure. Quotations } \\
\text { contradict or confuse } \\
\text { student's text. Quotations } \\
\text { used to replace student's } \\
\text { writing. }\end{array}$ \\
\hline Presentation & $\begin{array}{l}\text { Paper is clean, correctly } \\
\text { formatted (12-point font, } \\
\text { Times New Roman, normal } \\
\text { margins), written in full } \\
\text { sentences. Quotations are all } \\
\text { properly attributed and cited } \\
\text { in a consistent style. Virtually } \\
\text { no spelling or grammatical } \\
\text { errors. }\end{array}$ & $\begin{array}{l}\text { Paper is clean, correctly } \\
\text { formatted (12-point font, } \\
\text { Times New Roman, } \\
\text { normal margins), written } \\
\text { in full sentences. } \\
\text { Quotations are all } \\
\text { properly attributed and } \\
\text { cited in a consistent style. } \\
\text { A few minor spelling or } \\
\text { grammatical errors. }\end{array}$ & $\begin{array}{l}\text { Paper is clean, correctly } \\
\text { formatted (12-point font, } \\
\text { Times New Roman, } \\
\text { normal margins), written in } \\
\text { full sentences. Some } \\
\text { improperly attributed } \\
\text { quotations and/or } \\
\text { inconsistent citati-on style. } \\
\text { A number of spelling or } \\
\text { grammatical errors. }\end{array}$ & $\begin{array}{l}\text { Paper is sloppy or } \\
\text { incorrectly formatted, not } \\
\text { written in full sentences. } \\
\text { Many improperly } \\
\text { attributed quotations or } \\
\text { inconsistent style of } \\
\text { citation. Many spelling } \\
\text { or grammatical errors. }\end{array}$ \\
\hline
\end{tabular}

Available from https://www.cmu.edu/teaching/assessment/examples/ourselevel-bycollege/ cfa/tools/reflectionpaper-cfa.pdf

The Carnegie Mellon (ECTECM) Eberly Center for Teaching Excellence Model is an alternative assessment guide model that is considered simpler than the TOEFL IBT Scoring Rubric, besides easier to be used as a guide for integrated Listening-Writing self-assessment (SALWS). Based on such considerations, ECTECM was used as a reference for assessing students' SALWS intentionally involved in this study. The MECTECM distinguishes the level of writing ability into four categories, namely Sophisticated (A), Very Competent (B), Competent (C) and Not Yet Competent (D) with 4 (four) evaluation criteria which include: Accuracy (Grasp of readings), Argument (in depth analysis), Clarity and Presentation. Table 3 presents various assessment standards as the criteria that should be used as a benchmark for Listening-Writing skills assessment.

\section{Relationship between CLLA, BLM, HOTS and SALWS}

CLLA (Cultural Language Learning Approach), BLM (Blended Learning), HOTS (Higher Order Thinking Skills) and SALWS (Self-Assessment on Listening-Writing Skills) are concepts and procedures used as materials to explore students' writing abilities. CLLA and BLM are methods related to the content of learning materials, HOTS is related to the level of thinking used to understand the material content, while SALWS is related to the model that is used as a reference for students' Listening-Writing skills assessment. Figure 5 shows the relationship between the application of Listening-Writing skills acquisition using CLLA, BLM, HOTS and SALWS. 


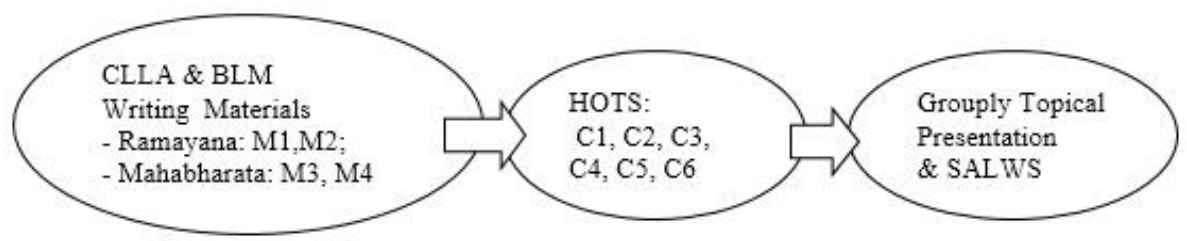

Figure 5. Model of Learning Writing Using CLLA, BLM, HOTS and SALWS

Concerning this project, Figure 5 illustrates that both CLLA and BLM were utilized as integrated learning approaches of students' writing capacities through understanding the contents of the wayang stories serial they just watched. Students' understanding on the learned stories content were, then used as the basic of writing their ideas or comments regarding the contents and the hidden moral values embedded in each of the stories. In such activities, not only LOWS (Lower Order Thinking Skills) e.g. C1, C2, C3 levels but also HOTS (Higher Order Thinking Skills) e.g. C4, C5, C6 are crucially needed. In this case, learners were given writing tasks in groups of three or depending on the classroom condition. The group work writing results were, then exchanged to other group to assess. This might be also self-assessed by the concerned group. Grouply Topical Classroom presentation or discussion concerning the content, embedded moral values and the results of SALWS (Self-Assessment on Listening-Writing Skills) using the suggested Scoring Rubrics was, afterwards, conducted undermonitored by the teacher.

\section{Materials and Methods}

This study was conducted at the English Education Study Program, Faculty of Teachers Training and Education located at one of the reputable private universities in Indonesia. It was conducted for the sake of actualising one of the aforementioned university missions, namely: Improving the quality of education especially in the field of learning assessment through Paragraph Writing Course. A total of 30 students were involved as research subjects regarding SALWS (Self-Assessment on Listening-Writing Skills) using CLLA (Cultural Language Learning Approach), BLM / BLS (Blended Learning Model or Blended Learning Strategy) and HOTS (Higher Order Thinking) in an integrated way by using a single case study method.

According to Yin (2002: 85), case studies are researches on events in real life contexts. Descriptive case study research seeks to obtain a detailed information of certain events and phenomena on a particular object or subject (Sanjaya, 2013: 48). Appropriately with the problems being understudied, the researcher herself was employed as a primary data collector completed with documentation in the form of portfolios, observations on the students' Listening-Writing assignments and the results of the students' self-assessment. The assessment focused on the ability to write paragraphs both in the form of integrated macro and micro skills using integrated or mixed methods of CLLA, BLM and HOTS. Before doing writing activities, students must listen to various series of wayang stories that have been selected to be comprehend. The students' comprehension results, then, were used as the basic of either doing the instructed writing tasks and/or in accomplishing the tasks assessment in groups. The tasks were performed for 7 meetings with a frequency of 3 Semester Credit Unit (SCU) for each meeting by referring to the decided specific scoring rubrics as a guide of assessing the tasks, namely the Eberly Center for Teaching Excellence Carnegie Mellon Model (ECTECM).

McMillan and Schumamacher (2010) in Sanjaya (2013) stated that there are three types of mixed research, namely triangulation design, explanatory design and exploratory design. The triangulation design is categorized into four models, namely conference, data transformation, data validation and multilevel models. This study utilized the Convergence Model of Triangulation Design. Quantitative and qualitative data were collected and analyzed using each approach and the results were compared and interpreted by the researcher (ibid: 2013: 51). Figure 6 is the procedure for implementing a convergence model.

In this study, the writing assignments results were assessed by students themselves grouply by referring to the SALWS technique that was integrated with CLLA, BLM and HOTS guided by Rubric for Assessing Written Presentations model of Allen (2014) id est., the Eberly Center for Teaching Excellence Carnegie Mellon Model (MECTECM). The obtained data were analysed using descriptive analytic for the students' writing learning outcomes. The assessment results were descriptively interpreted using a convergence triangulation design model and then described as research findings (See Figure 6). 


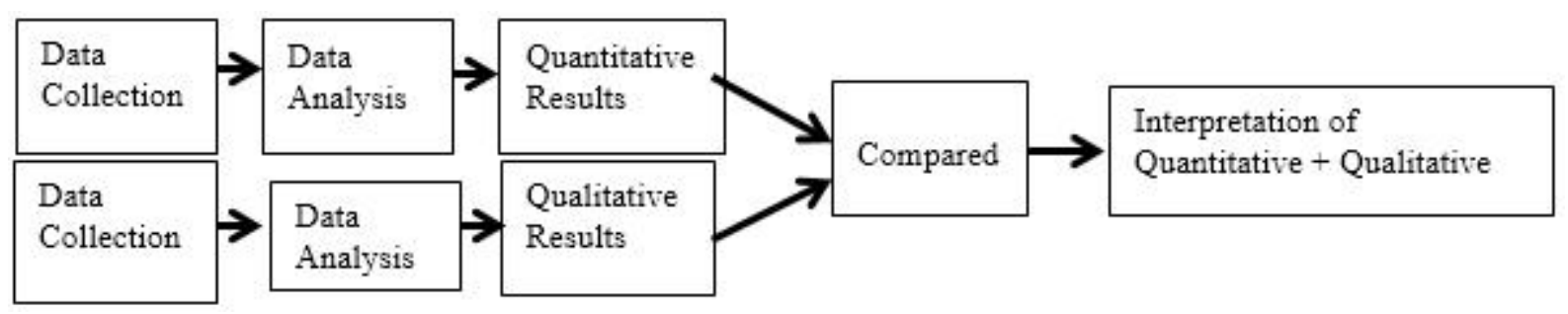

Figure 6. Model of Convergence Triangulation Design (Sanjaya, 2013: 51)

Table 4. Distribution of the results of the writing practice portfolio with an independent assessment

\begin{tabular}{|c|c|c|c|c|}
\hline Scoring Criteria & $\begin{array}{c}\text { Sophisticated (A) } \\
\text { Skor 85-100 }\end{array}$ & $\begin{array}{c}\text { Very Competent } \\
\text { (B) Skor 75-84 }\end{array}$ & $\begin{array}{c}\text { Competent ( C ) } \\
\text { Skor 65-74 }\end{array}$ & $\begin{array}{c}\text { Not Yet Competent } \\
\text { (D) Skor 40-64 }\end{array}$ \\
\hline Accuracy (Grasp of readings) & $0 \%$ & $6 \%$ & $61 \%$ & $33 \%$ \\
\hline Argument (depth of analysis) & & & & \\
\hline Clarity & & & & \\
\hline Presentation & & & & \\
\hline
\end{tabular}

(Inspired by the Eberly Center for Teaching Excellence Carnegie Mellon (ECTECM).

\section{Conclusions}

Data analysis included in-depth observations in seven paragraph writing test meetings indicating data analysis including the results of in-depth observations in seven paragraph writing test meetings indicated that the 30 students employed as this project participants: (1) were really well-involved during their paragraph writing activities; (2) studied the rubric assessment carefully to match their work with the criteria available in the copy provided by the Eberly Center Carnegie Mellon Model for Teaching Excellence (MECTECM) rubric assessment; (3) honestly assessed their own/fiends' work (they really valued themselves for who they were); and (4) appraised their work appropriately according to their factual abilities. Table 4 shows the distribution of scores from 30 students 'paragraph writing abilities and the average portfolio of students' writing assignments.

The scores distribution as shown in Table 4 illustrate the results of students' self-assessments using MECTECM. The evaluation on the paragraphs writing tasks were addressed to the four assessment aspects, namely: accuracy (Grasp of readings), argument (Depth of analysis), clarity (of the coherency) and presentation (of the work's performance). The assessment level consists of not yet competent (D), competent (C), very competent (B) and sophisticated (A) levels. In this matter, the lowest to highest scoring limit does not start from zero, but from 5.0 to 100 .

"A (the highest)" score will be obtained if the student reaches 85 to 100 ; " $\mathrm{B}$ " score is between 75 and 84 ; " $\mathrm{C}$ " score stretches between 65 and 74 and "D" score is between 50 and 64 . The scoring standard in this study was deliberately made higher because the lowest limit starts at 50 and there is no E score or below the score of 50. This standardization is based on psychological considerations, because $\mathrm{E}$ values can cause students to be inferior, demotivated, discouraged and dishearted) (McMullen, 2012; Meador, 2018; Peterman, 2019). In addition, giving bad grades letting alone turning off creativity indicates that teachers are less professional. Meador (ibid: 2019) asserts seven kinds of teachers' characteristics that are not good, one of which is negative assessment of students or poor judgment. Vice versa, increasing the motivation and ability of students, is the professional task of the teacher (Ministry of National Education of RI, 2015).

The results of the study showed that no one had reached the highest level of proficiency (A) with a score of 95 to 100. In other words, there was no one in the class included in the 'advanced' level. The average score spreads between $0 \%$ for the A (sophisticated) score, $6 \%$ for the B score (very competent), $71 \%$ for the $\mathrm{C}$ score (competent), and the remaining $11 \%$ for the $\mathrm{D}$ (Not yet competent) score. The range of scores is in accordance with the reality of their daily writing skills that have not all reached the average minimum score expected from the current graduation standard, which is B (around 75-84). In this case, there were only $6 \%$ ( 2 out of 30 students) who achieved scores of $\geq 75$, the rest $61 \%$ (18 people) got $\mathrm{C}$ scores and $33 \%$ ( 10 out of 30 students) got $\mathrm{D}$ scores. This could be problems, of course, particularly in the writing courses, such as essay writing, scientific papers or research proposal writing. Despite the fact, this problem has become a common barrier especially in TEFL (Teaching English as a Foreign Language) and it is still a 'scourge' for students. It is the duty of the lecturers to find new strategies in encouraging students to write, one of which is to assess their own work. A self-assessment strategy should continue to be tried in order to make them aware of their own abilities so they will strive to increase their efforts in achieving at least the minimum standard of mastery learning required as a graduation requirement.

Although the results of the study reveal the average level of students' writing skills in a cognitive manner is 
relatively not as expected, but there are some other important benefits regarding the development of attitudes (affective domain) that can be learned, namely practicing normative attitudes such as: honesty (for example in assessing their own works), discipline and responsibility (for example in carrying out tasks on time) that touches on the affective domain which is also demanded as consideration in the assessment. In addition, self-assessment can also be used as means to support the teachers' burden in examining the students' assigments that are piled up so that the available spare time can be used to carry out other demanded educational duties. However, lecturers are certainly obliged to provide feedback for each of the students' work that has been corrected by students to make sure whether or not their assessment tasks are well-corrected.

In addition to the results of the assessment as described above, the results of the study also showed that MECTECM was appropriately able to be used as an alternative model for assessing the students' Listening-Writing tasks independently (self-assessing). These activities provide benefits for the relevant lecturers among others, to minimize the accumulation of their academic work in addition to activating and testing the fairness or honesty of students in assessing their own works as demanded by the KKNI (Indonesian National Curriculum Framework), especially in accordance with the affective domain. As it is known, KKNI requires the development of three domains of educational taxonomy, namely cognitive (concerning intelligence of thought), affective (concerning attitude or behavior) and psychomotor skills (Krathwohl \& Anderson, 2001).

This research has gained the following outcomes. First, the SALWS Model (Self-Assessment for Listening-Writing Skills) whose actualization is integrated with CLLA, BLM, and HOTS. Second, students are well-acquired in implementing assessment techniques using the Eberly Center for Teaching Excellence Carnegie Mellon Model (ECTECM) model. Third, SALWS with ECTECM can be used by all students involved in this study by looking at the results, namely: the average score spread between $0 \%$ for A (sophisticated) score, 6\% B score (very competent), $71 \% \mathrm{C}$ score (competent) and the remaining $11 \%$ received $\mathrm{D}$ (Not yet competent) score. Fourth, the majority $(\geq 90 \%)$ of students are interested in learning WO. Thus it can be emphasized that the results of this study indicate the ability of students to independently evaluate their own Listening-Writing works, which means they can reduce the lecturers burden in correcting their students' writing work portfolios. Basically, aside by lecturers, assessments can be also carried out by peers or by students themselves using a predetermined assessment guide model.

\section{Acknowledgments}

This research was funded by Universitas Mercu Buana
Yogyakarta (UMBY). Therefore, the writer expresses her gratitude especially to the chancellor and chairman of Universitas Mercu Buana Yogyakarta Research Board along with the staffs and all parties involved in this project for their both financial and physical supports. Hopefully the results of this study will benefit the readers.

\section{REFERENCES}

[1] Allen, Marry.J. (2014). Using Rubrics to Grade, Assess, and Improve Student Learning. Miami: Miami-Dade College.

[2] Anderson, Lorin \& Krathwohl, David. (2001). Assessing: A Revision of Bloom's Taxonomy. New York: New York: US Publishing Co.

[3] Anonim. Sendratari Ramayana. https://sen1budaya.blogspot.com/2013/08/sendratari-rama yana-drama-dalam-tarian.html diunduh Februari 08, 2019

[4] Anonim. (2016). available at http://www.kaiamedia.com/pengertian-vlog retrieved January 27, 2018.

[5] Anonim. (2013). Sejarah Wayang di Indonesia. Diunduh April 20, 2013 dari http://supraba15.blogspot.com/2013/04/sejarah-asal-usulwayang.html

[6] Anonim. (February 08, 2019). Sekar Budaya Nusantara (SBN). Available from http://sekarbudayanusantara.co.id/Wynk/?page_id=520 downloaded February 08, 2019.

[7] Anonim. (2014). Independent Writing Rubrics. TOEFL iBT ${ }^{\circledR} \quad$ Test. $\quad$ Available from file://D:/ANY\%20PPM\%20FROM\%20\%202016/0.\%20P ROPPEN_DANA\%20UMBY\%202019/toefl_writing_rubr ics.pdf downloaded February 08, 2019

[8] Dafik. (2014). HOTS: Keterampilan berpikir Tingkat Tinggi. available at afik-fkip-unej.org/berita-199-keterampilan-berpikir-tingkat -tinggi-hots.html retrieved January, 2018).

[9] Depdiknas. (2015). Undang-Undang R.I No 14 Tahun 2015 tentang Guru dan Dosen. Jakarta: Depdiknas.

[10] Educational Testing service. (2014). TOEFL IBT Scoring Rubric.

USA:https://www.ets.org/s/toefl/pdf/toefl_writing_rubrics. pdf Downloaded February 09, 2019.

[11] Fulcher, Glenn \& Davidson, Fred. (2011). Language Testing and Assessment. New York: Routledge.

[12] Gemilang, Gilang. (2010). Sesaji 100 Tahun Wayang Orang Sriwedari. Available from https://aengaeng.com/2010/07/sesaji-100-tahun-waya ng-orang-sriwedari/ diunduh Februari 08, 2019

[13] King, FJ., Ludwika Goodson, Faranak Rohani. (2017). Higher Order Thinking Skills: Definition, Teaching Strategies, Assessment (A publication of the Educational 
Services Program, now known as the Center for Advancement of Learning and Assessment). retrieved January 29, 2018 from www.cala.fsu.edu.

[14] Merta Dhewa Kusuma, Undang Rosidin, Abdurrahman, Agus Suyatna. (2017). The Development of Higher Order Thinking Skill (HOTS) Instrument Assessment in Physics Study. IOSR Journal of Research \& Method in Education (IOSR-JRME) e-ISSN: 2320-7388, p-ISSN: 2320-737X Volume 7, Issue 1 Ver. III (Jan. - Feb. 2017), PP 00-00 www.iosrjournals.org

[15] Meador, Derick. (2018). 7 Characteristics of a Bad Teacher. Available from https://www. thoughtco.com/

[16] Mubaziroh. (2013). Gadget, Penggunaan dan Dampak pada Anak-Anak.http://jurnalilmiahtp2013.blogspot.co.id/2013/ 12/gadget-penggunaan-dan-dampak-pada-anak.html. Retrieved January 29, 2018)

[17] Rebecca. (2001). Integrated Skills in the EFL/ESL Classrooms. Oxford: Eric Digest.

[18] Sanjaya, Wina. (2013). Penelitian Pendidikan: Jenis, Metode dan Prosedur. Jakarta: Kencana Prenada Media Group.

[19] Setiadi, Hermayawati. (2017). Designing a Supplementary Reading Using Cultural Language Learning Approach (CLLA). International Journal for Innovation Education and Research www.ijier.net Vol:-5 No-08, 2017 Online-ISSN 2411-2933, Print-ISSN 2411-3123.

[20] Sugiyono. (2010). Metode Penelitian Pendidikan; Pendekatan Kuantitatif, Kualitatif, dan R\&D. Bandung: Alfabeta.

[21] Sukmadinata, Nana Syaodih. (2007). Metode Penelitian Pendidikan. Bandung: PT. Remaja Rosda Karya.

[22] The Duke of Kent KG. \& Sarah Kemp. (2015). Integrated Skills in English (ISE) Guide for Students - ISE II (B2). London: Trinity College.

[23] Yin, Robert K. (2005). Studi Kasus: Desain \& Metode. Jakarta: PT Raja Grafindo Persada.

[24] Thompson, Judy. (February 12, 2016). 6 Blended Learning Models: When Blended Learning Is What's Up For Successful Students available from https://elearningindustry.com/6-blended-learning-models-b lended-learning-successful-students 